\title{
Thermal and chemical characteristics of hot water springs in the northern part of the Limpopo Province, South Africa
}

\author{
J Olivier $^{1 *}$, JS Venter ${ }^{2}$ and CZ Jonker ${ }^{1}$ \\ ${ }^{1}$ Department of Environmental Sciences, UNISA, Private Bag X6, Florida 1710, South Africa \\ ${ }^{2}$ Council for Geoscience, Private Bag X112, Pretoria 0001, South Africa
}

\begin{abstract}
In many countries thermal springs are utilised for a variety of purposes, such as the generation of power, direct space heating, industrial processes, aquaculture and many more. The optimal use of a thermal spring is largely dependent upon its physical and chemical characteristics. This article focuses on the thermal and chemical features of 8 thermal springs located in the northern part of the Limpopo Province, South Africa. Field data and water samples were collected from Evangelina, Tshipise, Sagole, Môreson, Siloam, Mphephu, Minwamadi and Die Eiland for analysis of physical and chemical parameters. The temperatures at source vary from $30^{\circ} \mathrm{C}$ to $67.5^{\circ} \mathrm{C}$. The springs are associated with faults and impermeable dykes and are assumed to be of meteoric origin. The mineral composition of the thermal waters reflects the geological formations found at the depth of origin. None of the spring waters are fit for human consumption since they contain unacceptably high levels of bromide ions. Six springs do not conform to domestic water quality guidelines with respect to fluoride levels. Unacceptably high values of mercury were detected at Môreson and Die Eiland. Spring water at Evangelina is contaminated with selenium and arsenic. It is important to keep such limitations in mind when determining the ultimate use of the thermal springs.
\end{abstract}

Keywords: thermal springs, South Africa, macro and micro-elements, geological controls

\section{Introduction}

A spring is described as a concentrated discharge of groundwater that appears at the surface as a current of flowing water (Todd, 1980). Springs that discharge water which has a temperature above that of the normal local groundwater are called thermal springs (Todd, 1980). Thermal springs are natural geological phenomena that occur on all continents. Archaeological evidence shows that thermal springs have been in use for religious and/or medicinal purposes since before $2000 \mathrm{BC}$ in India and for hundreds of years in Crete, Egypt, China, Japan, Turkey and many European and Middle-Eastern countries (Encarta Encyclopaedia, 1997). Many thermal springs developed into flourishing centres of religion, culture and health, such as those at Bath in England, Vichy in France and BadenBaden in Germany.

The socio-economic importance of thermal springs has fluctuated over time (Booyens, 1981; Sanner, 2000; Atkinson and Davidson, 2002; Edmunds, 2004), but over the past few decades there has been an unprecedented resurgence of interest in this resource, mainly due to a diversification in the application of the waters (Christopher and Armstead, 1978; Samsudin et al., 1997). In addition to the increasing popularity of spas and the growing importance attached to the 'natural' health industry (Smith and Puczkò, 2009), thermal spring waters are increasingly being used for power generation, industrial processing, agriculture, aquaculture, bottled water and the extraction of rare elements (Vimmerstedt, 1998; Lund, 2000; Baradács et al., 2001; Lund and Freeston, 2001; Shevenell et al., 2002; Bahati, 2003; Hellman and Ramsey, 2004; Petraccia et

\footnotetext{
* To whom all correspondence should be addressed.

푱 +27 12543 0185; fax: +27 12543 0185;

e-mail: jana1@mweb.co.za

Received 15 February 2011; accepted in revised form 5 September 2011.
}

al., 2005). In 2005, 72 countries reported on the direct utilisation of geothermal energy (Lund et al., 2005). According to Lund (2010), in 2009, global direct-use projects were estimated to have had an installed thermal capacity of $50583 \mathrm{MW}$, with a thermal energy usage of $121696 \mathrm{GWh}$ per annum. A relatively recent development is the identification and use of thermophilic bacteria for possible industrial purposes (Zvauya and Zvidzai, 1995; Mawaza and Zvauyva, 1996; Mawadza et al., 2000;

Haring et al., 2005; Narayan et al., 2008).

In contrast to other countries, South African thermal springs are some of the most under-researched and under-utilised of all natural resources. However, the increasing recognition of the value of geothermal resources suggests that there will be a rekindling of interest in South African thermal springs in the near future. However, it is important that care should be exercised in the type of development that occurs. For example, it cannot be assumed that all spring water is pure, since many naturallyoccurring minerals are harmful or even dangerous to human and animal health. A number of studies have found that geothermal water may contain toxic elements such as arsenic and mercury (Mandal and Suzuki, 2002; Romero et al., 2003; Churchhill and Clinkenbeard, 2005), radio-active elements (Kempster et al., 1996; Baradács et al., 2001) and pathogenic organisms such as the meningitis-causing Naeglerias fowleri (Sugita et al., 1999; Izumiyama et al., 2003; Craun et al., 2005) and Legionella pneumonia (Miyamoto et al., 1997).

To date over 90 thermal springs have been identified in South Africa, of which the Limpopo Province has more than any of the other provinces. A number of hot springs in Limpopo have been developed for recreational and tourism purposes, and at some water is bottled and sold for therapeutic purposes. At places, the thermal spring is the sole source of water for the entire resort. A few thermal springs remain in private hands for exclusive use by the land owner. There are a few - predominantly those located in previous homelands - that 


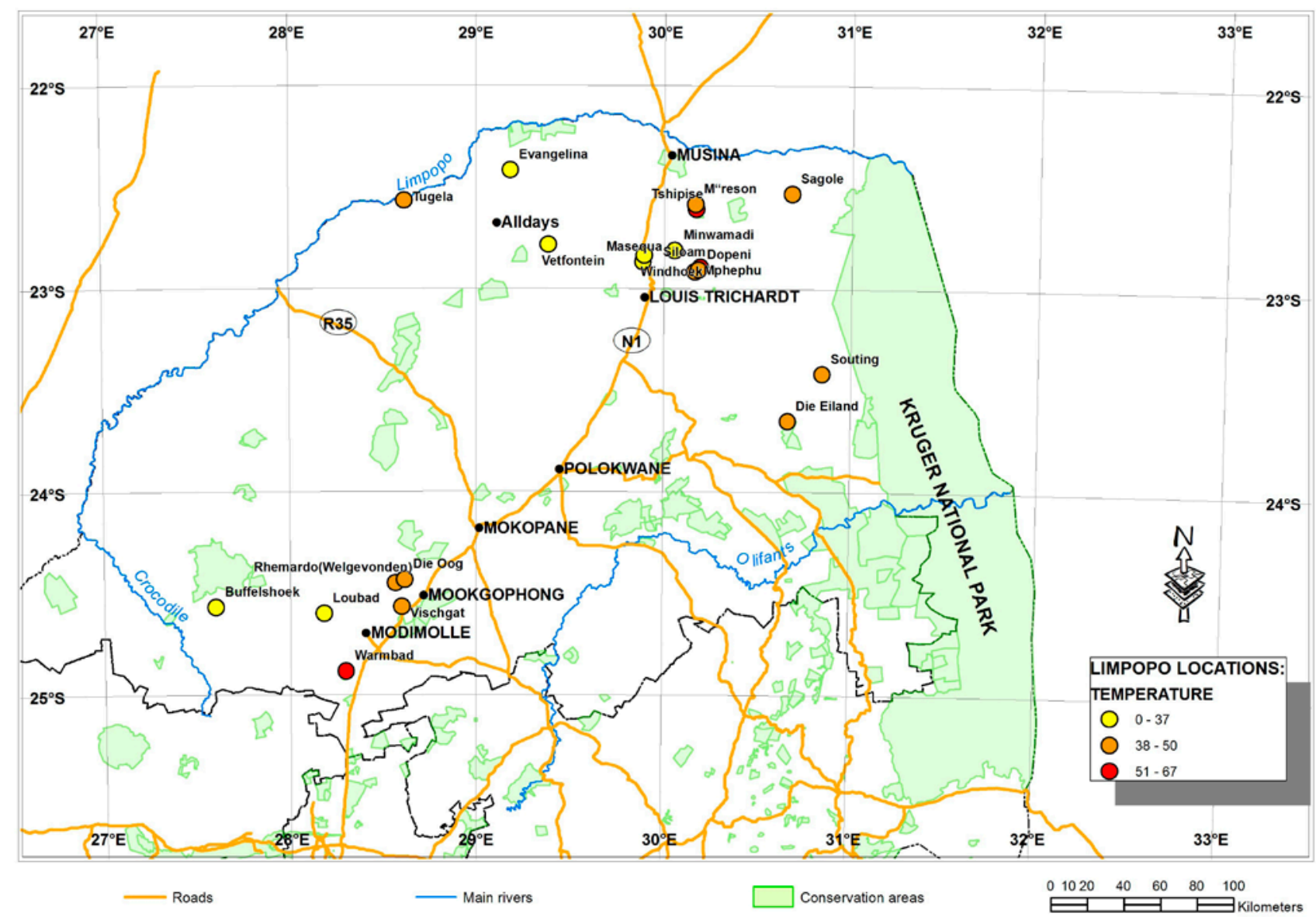

Figure 1

Location of thermal springs in Limpopo Province, South Africa Adapted from: Kent (1949) and Boekstein (1998)

remain completely undeveloped. The availability of current scientific information on these resources is a prerequisite for sound decision-making regarding their use and development. However, most research on South African thermal springs was conducted during the 1910s and 1950s. The past 50 to 100 years have seen considerable changes in land use but it is not known whether these have had an impact on thermal springs of the region.

This article presents current information on 8 thermal springs located in the northern part of the Limpopo Province. Since the optimal use of a thermal spring is largely dependent on its physical and chemical characteristics, the article focuses on these aspects. Information is provided on the geological features of the study areas in view of their impact on the physical location of the springs and on their chemical characteristics Due to the fact that most developed thermal springs have been sealed off and pumps installed, flow rates could not be measured and are not discussed. Information from previous research has been included where possible so as to give an overview of the characteristics of thermal springs in the northern Limpopo Province, and to provide a benchmark for the present research.

A comprehensive overview of previous research on South African thermal springs is provided in Olivier et al. (2008). The contribution of researchers such as Rindl (1916) and Kent $(1949 ; 1952 ; 1969)$ are discussed, as well as theories on the origin, geographical distribution patterns and classification systems used for thermal spring waters. This article is the second reporting on the physical and chemical characteristics of South African thermal springs.

\section{Study area}

At least 24 of the 83 thermal springs and boreholes identified by Kent (1949) are located in the Limpopo Province (Fig. 1). They occur in 2 main regions, namely in the region of the Waterberg in the south and in the vicinity of the Soutpansberg in the north. Isolated springs are found to the east of the escarpment. This paper focuses on 8 thermal springs in that part of the province which is located north of the $24^{\circ} \mathrm{S}$ line of latitude, excluding those in the Kruger National Park.

\section{Data and methodology}

Perusal of published sources (Rindl, 1916; Janish, 1931; Kent, 1949; Winfield, 1980) and a variety of maps, including topographical maps and those produced by Kent (1949), Boekstein (1998) and Hoole (2001), indicate the existence of 20 thermal springs in the study area, namely Paddysland, Tugela, Evangelina, Icon, Vetfontein, Masecula, Windhoek, Mphefu, Chipise, Gordonia, Klein Chipise, Souting, Letaba, Sulphur Springs, Stindal, Adrianskop, Masequa, Siloam (Sendedzane), Minwamadi and Makutsi.

There appears to be some confusion in the naming of some of the springs. A number of springs have undergone changes in use, ownership and name and some of the springs could only be identified by means of comparison of geographical coordinates. For instance, Klein Chipise (Tshipese) is now called Sagole; Gordonia seems to coincide geographically with Môreson, 
and Letaba is now the popular holiday resort of Die Eiland. Other springs were recognisable from their original names, only their spelling having changed. Chipise is currently spelt Tshipise, and Mpefu has changed to Mphephu. In other instances, the identification of springs was more difficult. One such case in point is the spring near Mphephu. Kent (1949) mentions that the spring at Mpefu has 2 eyes located $1.5 \mathrm{~km}$ apart. In Winfield's report on the thermal springs of Venda, he lists 2 springs, namely, Mpefu and Siloam (Sendedzane), in close proximity to each other and having more-or-less the same geographical co-ordinates. Moreover, the description of Winfield's Siloam (Sendedzane) spring coincides with that of Kent's Mpefu. It is therefore assumed that Mpefu, Siloam and Sendedzane are one and the same.

The majority of the thermal springs are located in the far northern and north-western part of Limpopo. Stindal, Tugela, Paddysland, Evangelina, Icon, Sulphur springs, Vetfontein, Masequa, Masecula and Windhoek are located to the west of the main road linking South Africa to Zimbabwe (the N1), while Tshipise, Môreson, Sagole, Mphephu and Minwamadi are located to the east of the N1 between Louis Trichardt and Musina (Messina). These 15 springs are clustered together in a SW-NE belt coinciding with the central and western parts of the Soutpansberg range. Adrianskop is located in the bed of the Olifants River to the south of Polokwane, while Souting, Die Eiland and Makutsi are located to the east of the escarpment.

Field trips were undertaken during 2003, 2004, 2005, 2009 and 2010 to gather data from the springs in the northern part of Limpopo. According to local residents, the spring at Icon has dried up due to the extraction of large amounts of groundwater for agricultural production (Chidley, 1985). Apparently Masequa has also dried up while the thermal sources at Sulphur springs, Tugela, and Windhoek are thermal boreholes and not naturally-occurring springs. Vetfontein, Paddysland, Stindal, and Makutsi could not be located. The Souting springs issue within an extensive wetland. When visiting Mphephu, local residents indicated the presence of another hot spring, not previously documented by Kent. This will be referred to as Siloam, after the nearest village.

This article reports on the physical and chemical characteristics of 8 thermal springs visited during the field trips: Evangelina, Mphephu, Siloam, Minwamadi, Tshipise, Sagole, Môreson and Die Eiland. Information obtained from literature was used to augment data that could not be gathered during these field trips. Where possible, the temperature of the water was measured at the source of the springs using a laboratory quality glass mercury thermometer. In some cases, the source of the spring had been enclosed and was not accessible. Water samples were collected at source and stored at low temperatures (around $4^{\circ} \mathrm{C}$ ) in 1-litre sample bottles before being submitted to the Institute for Soil, Climate and Water at the Agricultural Research Council in Pretoria for chemical analysis. No gas samples were collected. It was not possible to collect flow rate data, since pumps have been installed at the majority of developed thermal spring resorts. Past flow rate data were obtained from Kent (1949), Kent and Russell (1950) and Hoffmann (1979) and have been included for the sake of completeness.

\section{Results and discussion}

\section{Geographical characteristics of selected thermal springs}

\section{Mphephu}

Mphephu and Siloam lie within the Nzhelele valley which is surrounded by the Soutpansberg mountain range. The Nzhelele
River drains the area and flows north-westwards towards the Nzhelele Dam. The Mphephu thermal spring is situated at the foot of the northern flank of the Tswime Mountain at an elevation of around $850 \mathrm{~m}$. There are 2 eyes approximately $1.5 \mathrm{~km}$ apart. The westernmost eye has been sealed off and the water used to fill the pools at the Mphephu holiday resort. During 2004, the temperature was measured from leaks of pipes near the source. A pool has subsequently been constructed at one of the eyes and the temperature of water bubbling from the ground could be measured.

The second eye is undeveloped and has been used by the Dopeni community for bathing ever since the Mphephu Resort was closed for general public use. Men and women are allocated specific times to bath in this thermal spring. Bars of soap were observed in the water and hence it was not possible to collect representative samples from the spring itself. The water flow rate appeared to be very low but constant, while irregular surges of gas escaped at intervals.

\section{Siloam}

This hot spring is situated in the Siloam village on the property of one of the members of the community. Siloam is situated approximately $2 \mathrm{~km}$ northeast of Mphephu at the foot of the south-western flank of the Tonondwe Mountain. The spring emerges on the bank of a small stream running through the settlement. Although the community members indicated that neither its flow rate nor the temperature has changed over the past 40 years, measurements since 2003/4 indicated that both have decreased over the past 7 years. Mineral encrustations were observed in pipes leading from the spring.

\section{Tshipise}

This spring is located within the Honnet Nature Reserve, approximately $36 \mathrm{~km}$ from Musina, just off the R525 to the Kruger National Park. The Tshipise hot spring is situated at the foot of a $188 \mathrm{~m}$ high hill, surrounded by fairly flat terrain. It is a very well-known and popular holiday resort with 58 chalets, many camping sites, a restaurant and numerous conference and recreational facilities. The actual spring has been changed into a tourism feature. A concrete structure with glass windows has been constructed around the source. This allows visitors to view the water as it bubbles from the ground and the variety of multicoloured algae growing on the sides and floor of the spring.

Water samples were collected from a tap located close to the source.

\section{Môreson (previously Gordonia)}

The Môreson hot spring is located approximately $5 \mathrm{~km}$ to the north-northwest of Tshipise on the R508 to Musina. It is presently administered as a private shareholding scheme. A total of 47 of the 50 stands have been developed. Some of the units/ stands can be rented from individual owners. The thermal spring has been fitted with a pump which is used to fill the swimming pool(s).

\section{Sagole}

Sagole, previously known as Klein Tshipise, is situated at Sagole village, approximately $57 \mathrm{~km}$ to the east of Tshipise. Thick growths of algae cover submerged rocks and the sides of the water course. Waters from the spring flow northwards into the Tshipise River.

During the 1970s and 80s the spa was developed as a holiday destination. It was less frequented than Tshipise, mainly 
due to its relative inaccessibility and the limited scale of development. Since then it has fallen into disrepair, although some efforts are currently being made to regenerate the spa. When visited in 2006, the spring was used as a waste dump by locals, but the area is being cleaned up.

\section{Evangelina}

At the time of the first field trip in 2003/4, Evangelina was being developed as a holiday resort with conference facilities. Boreholes had been sunk to augment the hot spring. Unfortunately the original source of the spring had been enclosed. Borehole- and spring-water was being used to fill a large open-air swimming pool. Temperatures ranging from 34 to $45^{\circ} \mathrm{C}$ were measured from the various boreholes.

\section{Die Eiland}

Die Eiland thermal spring, formerly known as Letaba, is located in the Limpopo lowveld, close to the Great Letaba River. It was utilised by local inhabitants as a source of salt long before European settlement. The salt was obtained by 'lixivating the mud through which the water issued and evaporating the resultant solutions over open fires in clay pots' (Kent, 1942: 35). According to Kent (1942), the spring has 5 eyes, issuing over a distance of $30 \mathrm{~m}$. Temperatures of the eyes range from $37^{\circ} \mathrm{C}$ to $42^{\circ} \mathrm{C}$.

The thermal spring has been developed as a resort. It boasts an indoor Hydro Spa, with water temperature regulated at $38^{\circ} \mathrm{C}$, as well as bubble jet baths and saunas (Boekstein, 1998). There are also more than 100 self-catering chalets, caravan sites, a restaurant, a few shops and many more recreational and sports facilities. It has the added tourism benefit of being surrounded by the Hans Merensky Nature Reserve and within easy driving distance of a number of other tourist attractions.

\section{Minwamadi}

Minwamadi lies on the Nzhelele Dam road, about $15 \mathrm{~km}$ from the Wyllies Poort junction with the Thohoyando road, near the village of Khabu. The spring arises a few hundred meters from the Nzhelele River, on the west-facing flank of the Maangami range. It is completely undeveloped and seems to be known only to local communities in the immediate vicinity of the spring.

\section{Geology}

The geology of the study area includes various lithologies of the Soutpansberg Group and Karoo Supergroup, as well as the Goudplaats-Hout River Gneiss Suite and the Beit Bridge Complex.

The surface geology at Dopeni and Mphephu is indicated as mainly sandstone and quartzite of the Wyllies Poort and Nzhelele Formations of the Soutpansberg Group (Messina Map Sheet (Geological Survey, 1981)). Barker et al. (2006) describe the Wyllies Poort Formation as a predominantly clastic succession, and comprising mainly sandstone and quartzite (resistant to weathering), with minor conglomerate shale and basaltic lava. According to the South African Committee for Stratigraphy (Barker et al., 2006), the basalts of the Musekwa Formation outcrop in the Siloam Valley. This basal lava layer was previously considered to be part of the Nzhelele Formation. The layer of basalt is followed by argillaceous and arenaceous sediments (Brandl, 1981).

Barely $5 \mathrm{~km}$ from Mphephu, the thermal spring at Siloam is underlain by basaltic lava of the Sibasa Formation. The basalt is responsible for the more undulating topography to the south of the Soutpansberg (Brandl, 1981). The Sibasa Formation contains minor interbedded quartzite, shale and conglomerate (Barker et al., 2006). Minwamadi is situated on the slopes of the mountain flanking the Nzhelele River. According to the Messina Map Sheet (Geological Survey, 1981), the underlying geology is sandstone, quartzite and red shaly sandstone of the Nzhelele Formation.

Even though Tshipise, Sagole (Klein Tshipise) and Evangelina are geographically far apart, all 3 thermal springs are underlain by rocks of the Karoo Supergroup. Sagole is underlain by sedimentary rocks and Tshipise by volcanic rocks of the Letaba Formation.

Kent (1969) described the reason for the thermal spring at Evangelina as a fault in Archaean granite-gneiss. According to the Alldays Map Sheet (CGS, 2000), the thermal spring is underlain by amphibolite and minor granulite of the Malala Drift Gneiss Suite.

Sagole is associated with the Klein Tshipise Fault, which locally is the contact between Karoo Supergroup rocks (Madzaringwe- and Mikambeni Formations) to the north and basalt of the Nzhelele Formation (Musekwa Formation) to the south of the fault (Messina Map Sheet (Geological Survey, 1981)). The Nzhelele Formation forms part of the Soutpansberg Supergroup. The Madzaringwe Formation comprises mainly micaceous sandstone, siltstone and shale (Johnson et al., 2006). Some coal seams may be present in this formation (Brandl, 1981). The Mikambeni Formation consists of mudstone, black shale and laminated sandstone with occasional thin coal seams (Johnson et al., 2006). The basaltic lava is described by Brandl (1981) to be greenish grey, slightly amygdaloidal and with fine to coarse grain sizes.

Tshipise is located close to the confluence of 2 faults, one of which is called the Tshipise Fault (Messina Map Sheet (Geological Survey, 1981). According to Kent (1969), the Karoo Supergroup rocks have a thickness of $2100 \mathrm{~m}$, and are underlain by Archaean granite. The Letaba Formation immediately underlying the spring at Tshipise comprises mainly basalt. The spring also lies close to a dolerite intrusion, and to the contact between the Letaba Formation and the Gumbu Group of the Beit Bridge Complex which underlies the spring at Môreson. The Gumbu Group comprises mainly calc-silicate rocks and marble (Brandl, 1981).

The underlying geology at Die Eiland (Letaba) and Souting (Soutini) is grey biotite gneiss and micmatite of the Goudplaats Gneiss (Tzaneen Map Sheet (Geological Survey, 1985)).

Table 1 summarises the geology and geological structures associated with the thermal springs under discussion. Information was obtained from literature and from perusal of geological maps of the area.

It should, however, be kept in mind that the surface geology does not necessarily reflect the true origin of the spring water or explain its particular characteristics. The origin must be sought and/or can be inferred from the chemical composition of the water, its temperature and the local geothermal gradient, and knowledge of the structural geology of the area.

\section{Thermal characteristics}

Table 2 lists the temperature measured at source (where the hot water issues at the Earth's surface). The second column indicates temperatures measured during the field trips in 2004, whereas the third column gives the corresponding temperatures as obtained from literature. 


\begin{tabular}{|c|c|c|c|}
\hline \multicolumn{4}{|c|}{$\begin{array}{c}\text { Table } 1 \\
\text { Geology and geological structures associated with thermal springs in the northern part of Limpopo. }\end{array}$} \\
\hline Sampling site & Description of surface geology & \begin{tabular}{|l|l} 
Lithostratigraphic Unit \\
\end{tabular} & Geological structure \\
\hline $\begin{array}{l}\text { Mphephu/ } \\
\text { Dopeni* }\end{array}$ & Sandstone and quartzite & $\begin{array}{l}\text { Wyllie's Poort and Nzhelele } \\
\text { Formations, Soutpansberg Group }\end{array}$ & $\begin{array}{l}\text { Reverse fault between Waterberg Group } \\
\text { quartzite and Dominion Reef lava } \\
\text { (Sendedzane) }\end{array}$ \\
\hline Siloam* & Basalt, minor tuff & $\begin{array}{l}\text { Sibasa Formation, Soutpansberg } \\
\text { Group }\end{array}$ & \\
\hline Minwamadi* & Quartzitic sandstone & $\begin{array}{l}\text { Nzhelele Formation, } \\
\text { Soutpansberg Group }\end{array}$ & \\
\hline Tshipise* & $\begin{array}{l}\text { Basalt, minor andesite } \\
\text { Cream-coloured sandstone } \\
\text { Dolerite sills and dykes } \\
\end{array}$ & $\begin{array}{l}\text { Letaba Formation, Lebombo } \\
\text { Group, Karoo Supergroup } \\
\text { Tshipise Member, Clarens } \\
\text { Formation, Karoo Supergroup } \\
\text { Karoo dolerite } \\
\end{array}$ & $\begin{array}{l}\text { Intersection of } 2 \text { post-Permian faults in } \\
\text { upper Karoo }\end{array}$ \\
\hline Môreson* & Calc-silicate rocks & $\begin{array}{l}\text { Gumbu Group, Beit Bridge } \\
\text { Complex }\end{array}$ & Fault in Archaean granite-gneiss \\
\hline Sagole* & 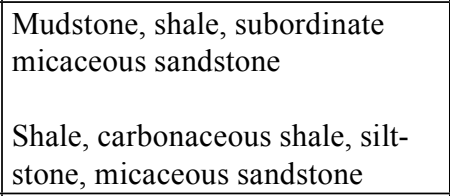 & $\begin{array}{l}\text { Mikambeni Formation } \\
\text { Madzaringwe Formation, Karoo } \\
\text { Supergroup } \\
\end{array}$ & \\
\hline Evangelina** & Amphibolite and minor granulite & Malala Drift Suite & Fault in Archaean gneiss \\
\hline Die Eiland*** & Leucocratic biotite gneiss & $\begin{array}{l}\text { Goudplaats - Hout River Gneiss } \\
\text { Suite }\end{array}$ & $\begin{array}{l}\text { Fissure associated with dolerite dyke and } \\
\text { fault in Archaean gneissic granite }\end{array}$ \\
\hline \multicolumn{3}{|c|}{$\begin{array}{l}\text { (According to the Geological Survey: 1:250 } 000 \text { Messina*; Alldays**; and } \\
\text { Tzaneen*** Map Sheets) }\end{array}$} & Source: Kent $(1949 ; 1969)$ \\
\hline
\end{tabular}

\begin{tabular}{|c|c|c|c|}
\hline \multicolumn{4}{|c|}{$\begin{array}{c}\text { Table } 2 \\
\text { Thermal characteristics of northern thermal springs (2004) }\end{array}$} \\
\hline Name & $\begin{array}{c}\text { Temperature } \\
\left({ }^{\circ} \mathrm{C}\right) \text { measured } \\
\text { at source } \\
(2004)\end{array}$ & $\begin{array}{c}\text { Temperature } \\
\left({ }^{\circ} \mathrm{C}\right) \text { extracted } \\
\text { from } \\
\text { literature }\end{array}$ & $\begin{array}{l}\text { Classification } \\
\text { (according to } \\
\text { Kent, 1949) }\end{array}$ \\
\hline Siloam & $\begin{array}{l}67.5 \\
\end{array}$ & & scalding \\
\hline Tshipise & 58 & $57.2(\mathrm{~K})$ & scalding \\
\hline Sagole & 45 & \begin{tabular}{|c|}
$45.9(\mathrm{~K}) ; 43.6$ \\
$(\mathrm{~W}) ; 49(\mathrm{~B})$ \\
\end{tabular} & hot \\
\hline Mphephu & 43 & $42.8 ; 43.7(\mathrm{~K})$ & hot \\
\hline Souting & & $43.9(\mathrm{~K})$ & hot \\
\hline Tugela & & $42.8(\mathrm{~K})$ & hot \\
\hline Môreson & 43 & $37.7(\mathrm{~K})$ & hot \\
\hline Die Eiland & 42 & $40.4 ; 42(\mathrm{~K})$ & hot \\
\hline Evangelina & $29,34,45$ & $\begin{array}{l}32.5(\mathrm{~K}) ; 45 \\
(\mathrm{C})\end{array}$ & warm \\
\hline Makutsi & & $35(\mathrm{~B})$ & warm \\
\hline Minwamadi & & $31.6(\mathrm{~W})$ & warm \\
\hline Sulphur Springs & & $31(\mathrm{~K})$ & warm \\
\hline Vetfontein & & $29.5(\mathrm{~K})$ & warm \\
\hline Paddysland & & $26(\mathrm{R})$ & warm \\
\hline \multicolumn{4}{|c|}{$\begin{array}{l}\text { Source: R: Rindl (1916); K: Kent (1949); W: Winfield (1980); } \\
\text { C: Chidley (1985); B: Boekstein (1998) }\end{array}$} \\
\hline
\end{tabular}

Two of the springs in the northern part of Limpopo can be classified as scalding, six are hot, and six are warm. The temperatures of another six are not known. Perusal of Fig. 1 and Table 2 indicates that there is no spatial correlation between the location of springs and their thermal characteristics. Tshipise, for instance, has a temperature of $58^{\circ} \mathrm{C}$, while Môreson, about $8 \mathrm{~km}$ away, is only around $40^{\circ} \mathrm{C}$. A difference of around $20^{\circ} \mathrm{C}$

occurs between Mphephu $\left(43^{\circ} \mathrm{C}\right)$ and Siloam $\left(60+^{\circ} \mathrm{C}\right)$, less than $5 \mathrm{~km}$ apart.

It is generally assumed that Brandvlei is the hottest thermal spring in South Africa $\left(64^{\circ} \mathrm{C}\right)$. However, in 2004 Siloam was $3.5^{\circ} \mathrm{C}$ hotter. Contrary to the situation at other springs, both the temperature and flow rates at Siloam have decreased over the past few years, measuring only $62^{\circ} \mathrm{C}$ in 2010 . At the other springs, the temperatures are essentially the same as they were in the 1940s and 1950s. It is expected that these will remain the same in the foreseeable future.

\section{Chemical characteristics}

\section{Major elements and ions}

Thermal springs are usually mineralised to a greater or lesser extent depending on the characteristics of the geological formations associated with the circulating groundwater (Todd, 1980). The results of the chemical analyses of water samples collected from the 8 springs in this study are given in Table 3 . Where available, data for 2004 and 2010 are given. Water quality standards provided by the South African Bureau of Standards (SABS) 1999 for Class 1 potable water are given to facilitate evaluation of water quality.

With minor exceptions, the 2004 and 2010 values are similar and do not indicate any significant variation during this 6-year period. It is therefore most probable that the composition of the other springs has also remained constant over the short term.

Water samples from the 8 northern Limpopo springs share a number of chemical characteristics. With the exception of Minwamadi, the springs have a $\mathrm{pH}$ of around 8; are neutral (neither corrosive nor depositional: $\mathrm{pH}_{\mathrm{s}}-\mathrm{pH}=-1$ to +1 ) and have sodium adsorption ratios (SAR) of more than 1 . The latter 


\begin{tabular}{|c|c|c|c|c|c|c|c|c|c|}
\hline \multicolumn{10}{|c|}{$\begin{array}{c}\text { Table } 3 \\
\text { Chemical composition }\end{array}$} \\
\hline & SABS 1999 & Mphephu & Siloam & $\begin{array}{c}\text { Minwa- } \\
\text { madi }\end{array}$ & Tshipise & Sagole & Môreson & Evangelina & $\begin{array}{c}\text { Die } \\
\text { Eiland }\end{array}$ \\
\hline $\begin{array}{l}\text { Date of } \\
\text { measurement }\end{array}$ & & $2004 ; 2010$ & $2004 ; 2010$ & 2010 & $2004 ; 2010$ & $2004 ; 2010$ & 2004 & 2004 & 2004 \\
\hline $\mathrm{pH}$ (lab) & $6-9$ & $8.10 ; 8.08$ & $8.92 ; 9.51$ & 7.35 & $8.30 ; 8.85$ & $8.72 ; 9.70$ & 8.55 & 7.49 & 7.63 \\
\hline $\mathrm{pH}_{\mathrm{s}}$ & $\mathrm{pHs}-\mathrm{pH} \pm 1$ & $8.24 ; 8.19$ & $8.50 ; 9.23$ & 8.60 & $8.70 ; 8.94$ & $8.91 ; 9.24$ & 8.93 & 7.29 & 7.67 \\
\hline SAR & $<1^{*}$ & $1.99 ; 2.15$ & $2.83 ; 14.82$ & 0.52 & $15.93 ; 25.43$ & $8.11 ; 15.01$ & 11.92 & 8.88 & 20.58 \\
\hline TDS & $<450$ & $175.90 ; 199.36$ & $\begin{array}{l}157.93 \\
197.32\end{array}$ & 104.74 & $422.10 ; 460.56$ & $\begin{array}{l}173.98 \\
203.76\end{array}$ & 340.55 & 1385.00 & 1937.2 \\
\hline $\begin{array}{l}\text { Conduct. } \\
(\mathrm{mS} / \mathrm{m})\end{array}$ & $<150$ & $34.00 ; 44.00$ & $29.00 ; 39.00$ & 24.00 & $80.00 ; 81.00$ & $33.00 ; 39.00$ & 57.00 & 230.00 & 330.00 \\
\hline \multicolumn{10}{|c|}{ Cations (mg/e) } \\
\hline Sodium & $<200$ & $40.14 ; 44.37$ & $41.36 ; 66.24$ & 10.59 & $\begin{array}{c}140.19 ; 156.31 \\
(140.9)[143] \\
\end{array}$ & $58.46 ; 65.15$ & 99.23 & $\begin{array}{l}360.90 \\
(343.8) \\
\end{array}$ & $621.88[305]$ \\
\hline Potassium & $<50$ & $1.35 ; 1.14$ & $2.42 ; 2.82$ & 0.99 & $\begin{array}{c}3.51 ; 4.25 \\
(2.2)[4] \\
\end{array}$ & $1.05 ; 1.10$ & 3.24 & 6.15 & $21.79[14]$ \\
\hline Calcium & ns & $13.35 ; 13.73$ & $1.38 ; 1.40$ & 9.36 & $\begin{array}{c}2.84 ; 5.58 \\
(6.0)[2] \\
\end{array}$ & $3.93 ; 1.31$ & 4.80 & 79.37 (78.8) & $53.61[32]$ \\
\hline Magnesium & ns & $10.60 ; 11.25$ & $0.08-1.30$ & 13.33 & $\begin{array}{c}0.01 ; 0.17 \\
(1.3)[1]\end{array}$ & $0.00 ; 0.07$ & 0.27 & $27.60(29.4)$ & $9.37[2]$ \\
\hline \multicolumn{10}{|c|}{ Anions (mg/e) } \\
\hline Fluoride & $1.5 ; 1^{*}$ & $2.54 ; 3.16$ & $6.08-6.11$ & 0.18 & $5.08 ; 5.63$ & $0.72 ; 1.01$ & 3.69 & 6.50 & 2.24 \\
\hline Nitrate & $<6^{*}$ & $0.07 ; 2.12$ & $0.04-0.00$ & 8.17 & $0.39 ; 0.61$ & $0.00 ; 0.00$ & 23.79 & 19.97 & 2.69 \\
\hline Chloride & $<200$ & $32.93 ; 39.38$ & $43.44-44.35$ & 19.47 & $\begin{array}{c}158.60 ; 168.97 \\
(139.1)[136]\end{array}$ & $44.09 ; 47.85$ & 117.31 & 535.17 (443) & $\begin{array}{c}982.62 \\
473] \\
\end{array}$ \\
\hline Sulphate & $<400$ & $8.28 ; 9.26$ & $10.44-10.69$ & 2.98 & $\begin{array}{c}47.58 ; 53.17 \\
(27.6)[23]\end{array}$ & $17.78 ; 18.20$ & 48.18 & $\begin{array}{l}226.01 \\
(215.9)\end{array}$ & $\begin{array}{c}143.63 \\
{[41]}\end{array}$ \\
\hline Phosphate & ns & $0.00 ; 0.00$ & $0.00-2.69$ & 0.00 & $0.00 ; 0.00$ & $0.10 ; 0.00$ & 0.00 & 1.26 & 24.86 \\
\hline \multirow[t]{2}{*}{ Carbonate } & ns & $0.00 ; 0.00$ & $0.00-14.40$ & 0.00 & $\begin{array}{c}- \\
6.00(12)\end{array}$ & $16.50 ; 18.00$ & 13.50 & 0.00 & 0.00 \\
\hline & & $134.20 ; 151.28$ & $70.15-107.36$ & 80.52 & $\begin{array}{c}109.80 \\
126.88(103.5) \\
\end{array}$ & $\begin{array}{l}64.05 ; \\
102.48\end{array}$ & 54.90 & $\begin{array}{l}244.00 \\
(191.3) \\
\end{array}$ & 149.45 \\
\hline \multicolumn{10}{|c|}{$\begin{array}{l}\text { *DWF (1996); ns: not stipulated. } \\
\text { Values in round brackets: Kent (1949); } \\
\text { Values in square brackets: Mazor and Verhagen (1983) }\end{array}$} \\
\hline
\end{tabular}

indicates that they are not suitable for irrigation. According to Bond's classification (1946), Mphephu, Minwamadi, Siloam, Tshipise and Sagole are temporary hard carbonate waters (C) while Evangelina and Die Eiland are highly mineralised chloride-sulphate waters (A). Mazor and Verhagen (1983) classify Die Eiland and Tshipise as saline waters (936 to 2364 $\mathrm{mg} / \ell$ TDI). Using this criterion, Evangelina's water would also be classified as saline. In terms of major ions, only water from Minwamadi and Sagole are suitable for human consumption - the other springs having fluoride values exceeding the recommended South African Guidelines for Domestic Water Quality (DWAF, 1996) value of $1 \mathrm{mg} / \ell$.

A comparison of present research findings with those for Tshipise and Evangelina given by Kent in 1949 (Table 3, in brackets), reveals that the mineral compositions of the waters have remained largely constant over the last 60 years. Minor differences are probably due to differences in collection methods and analytical techniques, rather than fundamental changes in water chemistry. The reason for the difference between Mazor and Verhagen's data (1983) for Die Eiland and that obtained during field trips conducted for this study is not known.

A Piper diagram (Fig. 2) is used to illustrate the chemical character of the thermal spring waters and to identify the degree of correspondence between the source areas of the springs. The explanation of the Piper diagram is based on that of Johnston (1975) as given in Lloyd and Heathcote (1985).

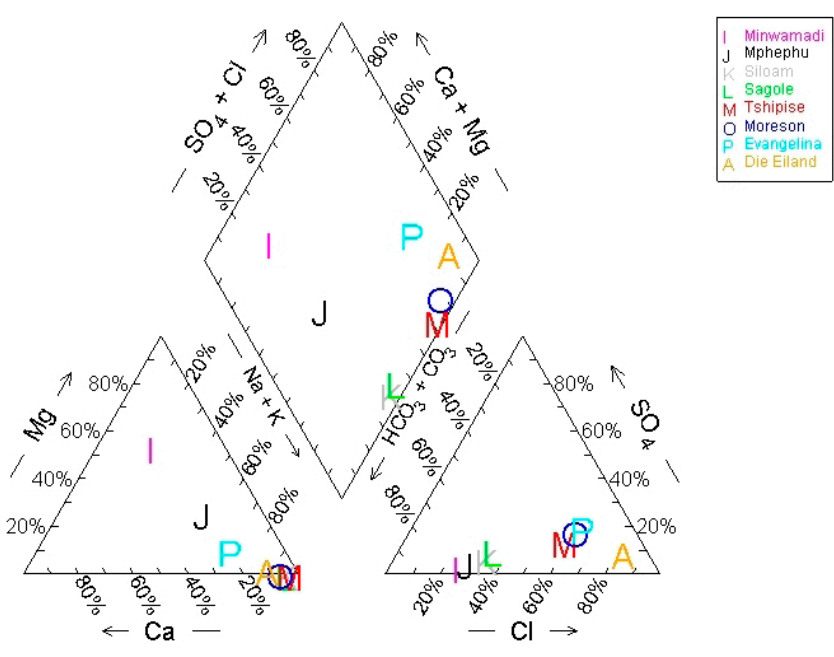

Figure 2

Piper diagram showing the chemical characteristics of northern Limpopo Province thermal spring waters

This diagram indicates that Môreson and Tshipise have very similar hydrochemical characteristics and therefore may share a common source area. The same principle seems to apply to Sagole and Siloam, despite their geographic distance apart. 
Môreson and Tshipise are typical sodium chloride brines, while, surprisingly, Die Eiland and, to a lesser extent, Evangelina, seem to share characteristics of sea water. The unusual composition of water at Die Eiland was also commented upon by Kent in 1942 (p. 40) who suggested a number of possible sources of the elements of this water. Most of the ions in the Eiland hot springs could have been acquired from the granite, and, to a lesser degree, diabase and basic rocks

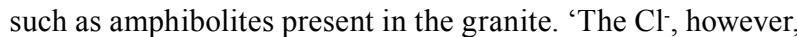
is not so readily accounted for' (Kent, 1942:40). Kent speculates that juvenile or rejuvenated water may contribute to the spring's flow and that there is a distinct possibility that it may be derived from cyclic salts dissolved by meteoric water. Kent also noted that part of the $\mathrm{Cl}^{-}$may have been derived from connate salts in the Karoo strata of the Lebombo Group. These salts could be blown in from the Indian Ocean $180 \mathrm{~km}$ to the east of Die Eiland. The difference between the cation composition of spring water and sea water may have come about from reactions between clays and base-exchange silicates.

Waters from Siloam, Sagole, Mphephu and Minwamadi have higher concentrations of $\mathrm{HCO}_{3}$ and $\mathrm{CO}_{3}$ ions than the other springs, which are higher in $\mathrm{Cl}^{-}$. In terms of cation concentrations, Minwamadi differs from the other springs in that it is richer in $\mathrm{Mg}$ ions. The $\mathrm{Na}^{+}$concentrations are very high at Môreson, Tshipise, Siloam, Sagole, and Die Eiland. None of the springs is rich in calcium and sulphate ions.

Most of the springs - with the possible exception of Minwamadi, Evangelina and Die Eiland - are typically those found in dynamic basin environments (Lloyd and Heathcote, 1985). The latter 3 springs fall just into the upper half of the diamond-shape figure. The dominant processes, at all except Mphephu and Minwamadi, are dissolution and mixing. It is surprising that waters from Minwamadi appear to be associated with recent dolomitic water since this spring is located in the Soutpansberg range. It is possible that it has been contaminated by human activity.

\section{Influence of geology on chemical characteristics}

The rocks forming the Soutpansberg Mountains consist of redcoloured sandstones and are underlain by voluminous basaltic lavas with interlaid volcanic ash beds of rhyolite (McCarthy and Rubidge, 2005). The high $\mathrm{Na}^{+}$concentrations at all springs, except for Die Eiland, Evangelina and Mimwamadi, probably originate from quartz and sodium-rich plagioclase feldspars from the sandstones and shales. At Minwamadi, the $\mathrm{Mg}^{2+}$ and $\mathrm{Ca}^{2+}$ may be associated with basaltic intrusions. These ions are also more abundant in waters from Mphephu than those from Siloam and might derive from sandstones, quartzites and some basaltic intrusions. The geology at Evangelina is extremely complex and it is thus difficult to speculate on the origin of the minerals in these waters. The unusual composition of Die Eiland has been mentioned by Kent $(1942 ; 1949)$ and has been discussed above.

According to Mazor and Verhagen (1983), less saline waters issue from crystalline rocks while the saline waters are associated with sedimentary rocks. However, according to the surface geology and that at depth, this does not seem to apply to northern Limpopo springs, with the possible exception of Evangelina.

\section{Trace elements}

Water samples from the 8 thermal springs visited were analysed for 29 trace elements by the Institute for Soil, Climate and Water (ARC, Pretoria). The information given in Table 4 comprises the most comprehensive dataset available to date.

Target ranges for domestic water quality for some of the trace elements are listed in Columns 2 and 3 as given by Mamba et al. (2008). The World Health Organisation (WHO) and European Union (EU) standards have been included since South African (SA) standards are at times less stringent than those used in other countries. WHO and EU standards are important in the event of bottling the water for the international market or for consumption by overseas visitors.

According to SA drinking water standards, all 8 thermal springs from the northern part of Limpopo contain 'unacceptably' high values of bromine while mercury levels exceed drinking water standards at Die Eiland and Môreson. The concentrations of selenium are also high at Die Eiland, Evangelina and Môreson. Evangelina has the poorest water quality of the 8 springs, exceeding recommended levels for bromine, selenium, and arsenic, and has very high levels of mercury, iodine, strontium, boron, titanium and vanadium. The water quality at Die Eiland is almost as poor, exceeding SA recommended levels for bromine, mercury and selenium. High concentrations of lithium, strontium and vanadium are also present at Die Eiland, relative to the other springs. The 'best' water qualities are found at Minwamadi, Sagole and Tshipise - even though they do not meet S A water quality standards for bromide. It should be noted that it is immaterial whether the elements in the water originate from the geological formations or from other sources: the fact remains that the long-term ingestion of water from these sources may be hazardous to human health.

\section{Summary and conclusion}

This article expands and enhances the present knowledge of the physical and chemical characteristics of 8 thermal springs in the northern region of the Limpopo Province of South Africa, and permits comparison with earlier findings so as to identify temporal variations in water quality over the last 50 to 60 years.

The springs are all of meteoric origin and range from warm to scalding in temperature. The mineral composition of the thermal waters probably reflects the geological formations that occur at the depth of origin of the thermal spring water rather than surface geology, since adjacent springs have disparate chemical properties. This implies that springs located in the same area may not have the same development potential.

The differences between $\mathrm{pH}_{\mathrm{s}}$ and $\mathrm{pH}$ values of most of the spring waters (except Minwamadi) are small (less than \pm 1 ), indicating that they are neither corrosive nor depositional in nature. However, SAR values of $>1$ counter-indicate their use for irrigation. Unacceptably high levels of fluoride are present in water from all of the thermal springs, except Minwamadi and Sagole, and none of the springs conforms to drinking water standards in terms of their bromine concentrations. The waters from the 8 thermal springs in the northern part of Limpopo are thus not fit for human consumption. The quality of waters from Die Eiland, Môreson and Evangelina are especially suspect in view of the relatively high selenium content.

Comparison of the physical and chemical characteristics of waters from Tshipise and Evangelina shows relatively little variation in temperature and the concentrations of major ions and trace elements. In contrast, the flow rate and temperature at Siloam has decreased considerably over a period of only 6 years. This seems to be coupled with lower rainfall over the region. At present no information is available on the residence time of waters that emerge as thermal springs. It is thus not known whether changes in land use may affect the mineral 


\begin{tabular}{|c|c|c|c|c|c|c|c|c|c|c|}
\hline \multicolumn{11}{|c|}{$\begin{array}{c}\text { Table } 4 \\
\text { Trace elements: Northern belt }\end{array}$} \\
\hline Element & $\begin{array}{c}\text { WHO* } \\
\text { and EU* }\end{array}$ & $\mathbf{S A}^{*}$ & Tshipise & Evangelina & Môreson & Sagole & Mphephu & $\begin{array}{c}\text { Minwa- } \\
\text { madi }\end{array}$ & Siloam & $\begin{array}{c}\text { Die } \\
\text { Eiland }\end{array}$ \\
\hline \multirow{2}{*}{$\begin{array}{l}\text { Date of } \\
\text { measurement }\end{array}$} & & & 2010 & 2004 & 2004 & 2010 & 2010 & 2010 & 2010 & 2004 \\
\hline & $\mathrm{ug} / \mathrm{l}$ & ug/e & $\mathrm{ug} / \ell$ & $\mathrm{ug} / \mathrm{l}$ & $\mathrm{ug} / \mathrm{l}$ & $\mathrm{ug} / \mathrm{l}$ & ug/l & $\mathrm{ug} / \mathrm{l}$ & ug/l & $\mathrm{ug} / \mathrm{l}$ \\
\hline Antimony & 5 & 5 & 0.02 & 1.39 & 1.14 & 0.31 & 0.02 & 0.01 & 0 & 0.48 \\
\hline Arsenic & 10 & 10 & 0.14 & 24.32 & 6.04 & 2.88 & 0.43 & 0.07 & 0.27 & 5.77 \\
\hline Barium & & & 13.63 & 14.18 & 25.76 & 5.14 & 51.90 & 1.88 & 4.22 & 78.74 \\
\hline Beryllium & & & 0 & 0.09 & 0.05 & 0 & 0 & 0 & 0 & 0.15 \\
\hline Bismuth & & & 0 & 0.60 & 0 & 0.02 & 0 & 0.02 & 0 & 0.71 \\
\hline Boron & & & 200.60 & 303.75 & 67.15 & 56.48 & 45.92 & 39.42 & 57.91 & 267.60 \\
\hline Bromine & 10 & & 366.30 & 1032.13 & 153.83 & 102.00 & 102.90 & 82.28 & 93.14 & 4111.00 \\
\hline Cadmium & & & 0.02 & 1.13 & 1.31 & 0.01 & 0 & 0.01 & 0 & 0.17 \\
\hline Chromium & 50 & 100 & 0.70 & 23.51 & 8.00 & 0.49 & 1.20 & 1.21 & 0.97 & 2.25 \\
\hline Cobalt & & & 0.10 & 1.22 & 0.11 & 0.01 & 0 & 0.02 & 0.05 & 2.07 \\
\hline Copper & 2000 & 1000 & 0 & 11.75 & 2.11 & 0 & 0 & 0 & 0 & 3.61 \\
\hline Iodine & & & 115.20 & 215.41- 2248.96 & 549.93 & 6.41 & 3.25 & 4.91 & 1.90 & 234.30 \\
\hline Lanthanum & & & 0.01 & 0.12 & 0 & 0 & 0.02 & 0.01 & nd & 0.18 \\
\hline Lead & 10 & 20 & 0.08 & 2.66 & 2.94 & 0.12 & 0.16 & 0.30 & 0.05 & 1.64 \\
\hline Lithium & & & 94.24 & 73.44 & 40.77 & 25.25 & 9.25 & 2.11 & 17.05 & 176.70 \\
\hline Manganese & 500 & 100 & 0 & 6.06 & 6.40 & 0.20 & 0 & 0.42 & 0.75 & 3.13 \\
\hline Mercury & 1 & 1 & 0.33 & 0.94 & 1.88 & 0 & 0.23 & 0 & 0.53 & 2.54 \\
\hline Molybdenum & & & 1.41 & 16.30 & 1.59 & 1.06 & 0.91 & 0 & 2.23 & 3.74 \\
\hline Nickel & 20 & 150 & 37.19 & 1.05 & 0 & 0 & 0 & 0 & 0 & 2.83 \\
\hline Platinum & & & 0.01 & $0.81-1.03$ & 0.10 & 0.07 & 0.01 & 0.0 & nd & 0.20 \\
\hline Selenium & 10 & 20 & 2.35 & 29.41 & 11.46 & 0.20 & 0 & 0.54 & 0.72 & 15.29 \\
\hline Strontium & & & 213,30 & 704.18 & 74.95 & 52.18 & 40.14 & 28.82 & 20.35 & 1018.00 \\
\hline Tellurium & & & 0 & $1.10-2.53$ & 0.99 & 0.03 & 0 & 0 & 0.02 & 0.46 \\
\hline Thallium & & & 0.01 & 0.32 & 0.31 & 0.02 & 0.04 & 0 & 0 & 0.41 \\
\hline Titanium & & & 3.03 & 299.20 & 30.24 & 4.01 & 3.09 & 1.01 & 6.14 & 8.44 \\
\hline Tungsten & & & 4.19 & 2.99 & 3.28 & 1.54 & 0.48 & 0.03 & 0.45 & nd \\
\hline Uranium & & & 0 & 26.05 & 1.12 & 0 & 0.45 & 0.09 & 0 & 8.53 \\
\hline Vanadium & & & 1.81 & 98.10 & 21.99 & 0.42 & 10.64 & 2.30 & 2.30 & 60.86 \\
\hline Zinc & 3000 & 5000 & 2.48 & 24.50 & 6.17 & 2.05 & 1.95 & 4.42 & 3.46 & 1738.00 \\
\hline
\end{tabular}

composition of the waters. Nevertheless, care should be taken in the type of land use practised in thermal spring catchment areas. It is clear that the present use of untreated thermal spring water for domestic purposes and as bottled drinking water is undesirable and may even be illegal. In addition, the use of thermal spring water for recreational purposes such as swimming should be closely monitored.

It is thus important that the physical and chemical composition of thermal springs be monitored on a regular basis and that any developers of thermal springs, albeit for present or future activities, should take cognisance of the chemical properties of the springs and should implement appropriate measures to minimise risk.

\section{Acknowledgements}

This research formed part of a NRF-funded project: Focus Area Sustainable Livelihoods (GUN: 2054058) in 2004, as well as a Water Research Commission project (WRC project No. K5/1959/1) in 2010). The support of these organisations, as well as that of the University of South Africa (2003), are gratefully acknowledged. We also wish to thank Ingrid Booysen (UP) for drafting the map.

\section{References}

ATKINSON TC and DAVIDSON (2002) Is the water still hot? Sustainability and the thermal springs at Bath, England. Geological Society, London, Special Publications 193 15-40.

BAHATI G (2003) Geothermal energy in Uganda, country update. Proc. International Geothermal Conference, September 2003, Reykjavik. pp. 48-53.

BARADÁCS E, HUNYADI I, DEZS Z, CSIGE I and SZERBIN P (2001) ${ }^{226} \mathrm{Ra}$ in geothermal and bottled mineral waters of Hungary. Radiat. Meas. 34 (1-6) 385-390.

BARKER OB, BRANDL G, CALLAGHAN CC, ERIKSSON PG and VAN DER NEUT M (2006) The Soutpansberg and Waterberg Groups and the Blouberg Formation. In: Johnson MR, Anhaeusser CR and Thomas RJ (eds.) The Geology of South Africa. Geological Society of South Africa, Johannesburg, and Council for Geoscience, Pretoria. 301-318.

BOEKSTEIN M (1998) Hot Springs Holidays: Visitors' Guide to Hot Springs and Mineral Spa Resorts in Southern Africa. Mark Boekstein and Logo Print, Cape Town.

BOJADGIEVA K, DIPCHIKOVA S, BENDEREV A and KOSEVA J (2002) Thermal Waters and Balneology in Bulgaria. GHC Bulletin March 18-25.

BOND GW (1947) 'n Geochemiese opname van die grondwatervoorrade van die Unie van Suid-Afrika. Memoir Geol. Surv. S. Afr. 41 90-94. 
BOOYENS B (1981) Bronwaters van Genesing - Die Tradisionele Warmbronwaterkultuur in Ons Volksgeneeskunde. Tafelberg, Kaapstad.

BRANDL G (1981) The Geology of the Messina Area. Explanation of 1:250 000 Sheet 2230. Geological Survey of South Africa (now Council for Geoscience), Pretoria.

CHIDLEY CM (1985) The geology of the country around Evangelina and Pontdrift. CGS Report No. 1985-0231. Council for Geoscience, Pretoria.

CHRISTOPHER H and ARMSTEAD H (1978) Geothermal Energy: Its Past, Present and Future Contributions to the Energy Needs of Man. E. and F.N Spon, London.

CHURCHILL RK and CLINKENBEARD JP (2005) Perspectives on mercury contributions to watersheds from historic mercury mines and non-mine mercury sources: examples from the sulphur creek mining district. Cordilleran Section $-101^{\text {st }}$ Annual Meeting. Piedmont, Italy, 29 April - 1 May 2005.

CGS (COUNCIL FOR GEOSCIENCE, SOUTH AFRICA) (2000) 1:250 000 Geological Series Alldays Map Sheet 2228. Council for Geoscience, Pretoria.

CRAUN GF, CALDERON RL and CRAUN ME (2005) Outbreaks associated with recreational water in the United States. Int. J. Environ. Health Res. 15 (4) 243-262.

DWAF (DEPARTMENT OF WATER AFFAIRS AND FORESTRY, SOUTH AFRICA) (1996) South African Water Quality Guidelines. Domestic Water Quality. URL: http://www.dwaf.gov.za (Accessed 13 December 2006)

EDMUNDS WM (2004) Bath thermal waters: 400 years in the history of geochemistry and hydrogeology. Geological Society, London, Special Publication 225 193-199.

ENCARTA ENCYCLOPEDIA (1997) Microsoft.

GEOLOGICAL SURVEY (1981) 1:250 000 Geological Series; Map Sheet 2230 Messina.

GEOLOGICAL SURVEY (1985) 1:250 000 Geological Series; Map Sheet 2330 Tzaneen.

HARING M, RACHEL R, PENG X, GARRETT RA and PRANGISHVILI D (2005) Viral diversity in hot springs of Pozzuoli, Italy, and characterization of a unique archaeal virus, Acidianus bottle-shaped virus, from a new family, the Ampullaciridae. $J$. Virol. 79 (15) 9904-0011.

HELLMAN MJ and RAMSEY MS (2004) Analysis of hot mineral springs and associated deposits in Yellowstone National Park using ASTER and AVIRIS remote sensing. J. Volcanol. Geotherm. Res. 134 (1-2) 195-219.

HOFFMANN JRH (1979) Die chemiese samestelling van warmwaterbronne in Suid- en Suidwes-Afrika. CSIR Report No. WAT 56A. Council for Scientific and Industrial Research, Pretoria. pp 21.

HOOLE RG (2001) The development of Lilani hot spring: An analysis of socio-economic and environmental impacts. M.Sc. Dissertation, University of Natal, Pietermaritzburg, South Africa.

IZUMIYAMA S, YAGITA K, FURUSHIMA-SHIMOGAWARAM ASAKURA T, KARASUNDANI T and ENDO T (2003) Occurrence and distribution of Naegleria species in thermal waters in Japan. J. Eukaryotic Microbiol. 50 (1) 514.

JANISH EP (1931) Notes on the central part of the Zoutpansberg Range and on the origin of Lake Fundudzi. Trans. Geol. Soc. 34 151

JOHNSON MR, VAN VUUREN CJ, VISSER JNJ, COLE DI, DE V WICKENS H, CHRISTIE ADM, ROBERTS DL and BRANDL G (2006) Sedimentary Rocks of the Karoo Supergroup. In: Johnson, MR, Anhaeusser CR and Thomas RJ (eds.) The Geology of South Africa. Geological Society of South Africa, Johannesburg, and Council for Geoscience, Pretoria. 461-499.

KEMPSTER PL, VAN VLIET HR, LOOSER U, PARKER I, SILBERBAUER MJ and DU TOIT P (1996) Overview of Radioactivity in Water Sources: Uranium, Radium and Thorium. Institute for Water Quality Studies, Department of Water Affairs and Forestry, South Africa.

KENT LE (1942) The Letaba Hot Spring. Trans. R. Soc. S. Afr. 29 (2) 35-47.

KENT LE (1949) The thermal waters of the Union of South Africa and South West Africa. Trans. Geol. Soc. S. Afr. 52 231-264.
KENT LE (1952) The Medicinal Springs of South Africa. Publication and Travel Department, South African Railways, Pretoria.

KENT LE (1969) The thermal waters in the Republic of South Africa In: Proc. of Symposium II on Mineral and Thermal Waters of the World, B-Overseas Countries, Vol 19, Report of the $23^{\text {rd }}$ Session of the International Geological Conference, 1968, Academia, Prague. 143-164.

KENT LE and RUSSELL HD (1950) The warm spring on Buffelshoek, near Thabazimbi, Transvaal. Trans. R. Soc. S. Afr. 32 161-175.

LLOYD JW and HEATHCOTE JA (1985) Natural Inorganic Hydrochemistry in Relation to Groundwater. Clarendon Press, Oxford.

LUND JW (2000) Balneological use of thermal water in the USA. GHC Bulletin September 2000 31-34.

LUND JW (2010) Keynote address: World Geothermal Conference, 25 April, 2010, Bali, Indonesia.

LUND JW and FREESTON DH (2001) World-wide direct uses of geothermal energy 2000. Geothermics 30 29-68.

LUND JW, FREESTON DH and BOYD TL (2005) Direct application of geothermal energy: 2005 Worldwide Review. Geothermics 34 (6) 691-727.

MANDAL BK and SUZUKI KT (2002) Arsenic round the world: a review. Talanta 58 (1) 201-235.

MAMBA BB, RIETVELD LC and VERBECK JQJC (2008) SA drinking water standards under the microscope. The Water Wheel 7 (1) 24-27.

MAWADZA C and ZVAUYA R (1996) Some factors affecting endob-1,4-glucanase production by two Bacillus strains isolated from Zimbabwean hot springs. J. Basic Microbiol. 36 (3) 177-187.

MAWADZA C, HATTI-KAUL R, ZVAUYA R and MATTIASSON B (2000) Purification and characterization of cellulases produced by two bacillus strains. J. Biotechnol. 83 (3) 177-187.

MAZOR E and VERHAGEN BT (1983) Dissolved ions, stable and radioactive isotopes and noble gases in thermal waters of South Africa. J. Hydrol. 63 315-329.

McCARTHY T and RUBIDGE B (2005). The Story of Earth and Life. Struik, Cape Town.

MIYAMOTO H, JITSURONG S, SHIOTA R, MARUTA K, YOSHIDA S and YABUUCHI E (1997) Molecular determination of infection source of a sporadic Legionella pneumonia case associated with a hot spring bath. Microbial Immunol. 41 (3) 197-202.

NARAYAN VN, HATHA MA, MORGAN HW and ROA D (2008) Isolation and characterization of aerobic thermophilic bacteria from the Savusavu hot spring in Fiji. Microbes Environ. 23 (4) 350-352.

OLIVIER J, VAN NIEKERK HJ and VAN DER WALT IJ (2008) Physical and chemical characteristics of thermal springs in the Waterberg area of Limpopo Province, South Africa. Water SA 34 (2) $163-174$.

PETRACCIA L, LIBERATI G and MASCIULLO SG (2005) Water, mineral waters and health. Clin. Nutr. 25 (3) 377-385.

RINDL MR (1916) The medicinal springs of South Africa. S. Afr. J. Sci. 13 528-552.

ROMERO L, ALOMSO H, CAMPANO P, FANFANI L, CIDU R, DADEA C, KEEGAN T, THORNTON I and FARAGO M (2003) Arsenic enrichment in waters and sediments of the Rio Loa (Second Region, Chile). Appl. Geochem. 18 (9) 1399-1416.

SAMSUDIN AR, HAMZAH U, RAHMAN RA, SIWAR C, JANI MF and OTHMAN R (1997) Thermal springs of Malaysia and their potential development. J. Asian Earth Sci. 15 275-289.

SANNER B (2000) Baden-Baden, a famous thermal spa with a long history. GHC Bulletin September 2000 16-22.

SHEVENELL L, GARSIDE L, AREHART G, VAN SOEST M and KENNEDY BM (2002) Geothermal sampling of thermal and nonthermal waters in Nevada to evaluate the potential for resource utilization. Geotherm. Resour. Counc. Trans. 26 (September 22-25) 501-505.

SABS (SOUTH AFRICAN BUREAU OF STANDARDS) (1999) Class 1 Potable Water Standards. SABS 241:1999. South African Bureau of Standards Pretoria, South Africa.

SMITH M and PUCZKÒ L (2009) Health and Wellness Tourism. Elsevier, Oxford. 
SUGITA Y, FUJII T, HAYASHI I, AOKI T, YOKOYAMA T, MORIMATSU M, FUKUMA T and TAKAMIYA Y (1999) Primary amebic meningoencephalis due to Naegleria fowleri: An autopsy case in Japan. Pathol. Int. 49 (5) 468-470.

TODD, DK (1980) Groundwater Hydrology (2 $2^{\text {nd }}$ edn.). Wiley, New York.

VENTER JS and VAN WYK NA (2008) Field report for the Limpopo Field Trip: Hot springs of southern Africa. CGS Report no. 20080196. Council for Geoscience, Pretoria.
VIMMERSTEDT LJ (1998) Opportunities for small geothermal projects: Rural power for Latin America, the Carribbean and the Philippines. Natural Renewable Energy Laboratory, Colorado, USA.

WINFIELD D (1980) The thermal springs of Venda. Report on desk study and visit to Venda, July 1980. Mining Corporation Limited. $\mathrm{RD} / \mathrm{OW} / 1138$.

ZVAUYA R and ZVIDZAI CJ (1995) Constitutive production of endoglucanase by Bacillus sp. isolated from Zimbabwean hot spring. World J. Microbiol. Biotechnol. 11 658-660. 